\title{
MIĘDZYNARODOWE SYSTEMY CERTYFIKACJI LEED, BREEAM I DGNB. WSTEPNA ANALIZA PORÓWNAWCZA POPARTA STUDIUM PRZYPADKU
}

\begin{abstract}
Artykuł podejmuje zagadnienie certyfikacji budynków za pomocą międzynarodowych systemów certyfikacji LEED, BREEAM, DGNB.W Polsce jak i w całej Unii Europejskiej sektor budowlany pochłania najwięcej energii - około $40 \%$ całkowitego zużycia. W związku ze zmieniającymi się przepisami Unii Europejskiej, a także z rosnącą świadomością ekologiczną społeczeństw coraz częściej porusza się temat zmiany podejścia do projektowania i realizacji obiektów budowlanych. Nowoczesne budynki powinny być obiektami, przy których w każdej fazie procesu powstawania - od wyboru działki, poprzez projekt i realizację, kończąc na użytkowaniu ogranicza się zużycie surowców to znaczy energii i wody, ogranicza się ilość odpadów, ale także stosuje się nowoczesne technologie i materiały. Opierając się na przeprowadzonych studiach literaturowych, oraz wykonanych analizach komparatywnych, autor opracował podstawowe zestawienie powyższych certyfikatów pod katem powszechności stosowania, a także rodzajów kryteriów, którymi się kierują, oraz wagą tych kryteriów. Na przykładzie budynku biurowego, który w procesie symulacji, został certyfikowany za pomocą każdego z systemów, wykazano, iż, certyfikaty mimo pozornych różnic, posiadają pewne cechy wspólne - w każdym systemie budynek uzyskałby certyfikat, jednak na różnym poziomie. W finalnej części artykułu, zostały sformułowane wstępne wnioski dotyczące aspektów ekonomicznych, społecznych i ekologicznych w systemach certyfikacji. Artykuł ma na celu syntezę informacji i dotychczasowych badań dotyczących najważniejszych cech systemów certyfikacji LEED, BREEAM I DGNB
\end{abstract}

Słowa kluczowe: certyfikacja, architektura, zrównoważony rozwój, energia

\section{Wprowadzenie}

Koncepcja zrównoważonego rozwoju, zaczęła być poważnie brana pod uwagę w rozwoju poszczególnych krajów od lat dziewięćdziesiątych dwudziestego wieku, umownie od przyjęcia deklaracji z Rio z w roku 1994 [1]. W tym okresie pojawiło się wiele definicji dotyczących tego modelu rozwoju, każda

${ }^{1}$ Martyna Mokrzecka Politechnika Wrocławska, Wydział Architektury ul. B. Prusa 53-55,

50-317 Wrocław, martyna.mokrzecka@pwr.edu.pl 
z nich bazuje jednak na trzech głównych aspektach tj. ekonomii, środowisku i aspekcie społecznym. Systemy certyfikacji wielokryterialnej budynków są w tym kontekście rozważane, jako narzędzia pozwalające na zmierzenie stopnia zaawansowania obiektów w spełnianiu przez nie zasad zrównoważonego rozwoju. Certyfikaty, które zostały wybrane do analizy charakteryzują się przede wszystkim dużym zasięgiem terytorialnym ich stosowania, a także popularnością. Pomimo, że w Polsce są dosyć nowym rozwiązaniem - pierwszy certyfikat został przyznany w 2010 roku, z roku na rok zdecydowanie zwiększa się ich popularność - obecnie jest ich 152 i ich liczba stale rośnie [2].

\section{Omówienie poszczególnych systemów certyfikacji}

\subsection{System LEED}

W chwili obecnej LEED (Leadership in Energy and Environmental Design) jest najpopularniejszym systemem certyfikacji na świecie. Ponad 30000 obiektów uzyskało certyfikat, z czego ok 3800 na poziomie Platinum [3]. Jest też drugim, co do popularności systemem w Polsce, 21 obiektów zostało już certyfikowanych, natomiast 64 obiekty są $\mathrm{w}$ procesie certyfikacji [2]. LEED jest systemem amerykańskim, powstałym w 1993 roku. Organem odpowiedzialnym za procesy i przyznawanie certyfikatów jest U.S Green Building Council. Oceną objęte są głównie budynki komercyjne, ale też mieszkalne, wnętrza itp. zarówno nowopowstające, jaki i istniejące. Jego głównymi celami są: zwiększenie wydajności budynków, obniżenie kosztów eksploatacji i zapotrzebowania na energię oraz zmniejszenie emisji gazów cieplarnianych. Obiekty są oceniane w pięciu kategoriach, w każdej kategorii przyznawana jest określona ilość punktów. Kategorie to: Zrównoważona lokalizacja (26 pkt), Efektywne wykorzystanie zasobów wodnych (10 pkt), Energia i atmosfera (35 pkt), Materiały i zasoby (14 pkt), Jakość środowiska wewnętrznego (15 pkt). Oprócz punktów podstawowych (100 pkt), mogą być też przyznane punkty dodatkowe - za innowacyjność (6 pkt) i regionalne priorytety $(4 \mathrm{pkt})$. Obiekty w zależności od przyznanych punktów, mogą zostać odznaczone certyfikatem na czterech poziomach: Certified (40-49 pkt), Silver (50-59 pkt), Gold (60 -79 pkt), Platinum (80 pkt. i więcej)

Aby otrzymać certyfikat należy spełnić osiem punktów krytycznych tj. zmniejszenie wpływu działalności budowlanej na otoczenie, poprzez erozję gleby i emisję płynów, zmniejszenie zużycia wody, weryfikacja systemów związanych $\mathrm{z}$ energią $\mathrm{w}$ budynku i ich kalibracja zgodnie $\mathrm{z}$ wartościami zamieszczonymi przez inwestora, minimalne wymagania dot. charakterystyki energetycznej budynku, podstawowe wymagania dot. systemów chłodniczych, zapewnienie miejsca do zbierania i przechowywania materiałów z recyclingu, minimalna, jakość środowiska wewnętrznego, kontrola środowiskowego dymu tytoniowego. 


\subsection{System BREEAM}

BREEAM (British Research Establishment Environmental Assesment Method) jest drugim, co do popularności certyfikatem na świecie. Ponad 250000 budynków jest certyfikowanych w tym systemie w 50 krajach świata. 40000 Kolejnych jest $w$ trakcie realizacji. [4]. Jest także najpopularniejszym systemem certyfikacji w Polsce. Pierwszy obiekt otrzymał go w 2009 roku, a obecnie posiada go 128 obiektów [2]. BREEAM jest systemem brytyjskim, najstarszym z omawianych w artykule certyfikatów - jest przyznawany od 1990 roku. Instytucja koordynująca i przyznająca certyfikat to BRE (Building Research Establishment) Podstawowym podziałem przy jego przyznawaniu jest rozróżnienie na budynki i zespoły urbanistyczne będące w użyciu, oraz nowopowstające. Od 2013 roku BREEAM funkcjonuje w wersji International, czyli dostosowanej do lokalnych warunków i przepisów. Obiekty oceniane są w następujących kategoriach: zarządzanie (do $12 \%$ pkt.), Zdrowie i samopoczucie (do $15 \%$ pkt.), energia (do 19\% pkt.), transport (do 8\% pkt.), woda (do 6\% pkt.), materiały (do 12,5\% pkt), Odpady (do 7,5\% pkt), zanieczyszczenia (do 10\% pkt.), Użycie terenu i ekologia (do 10\% pkt.), innowacja (do 10\% dodatkowo). W zależności od ilości punktów budynki mogą zostać ocenione w pięciostopniowej skali dla budynków projektowanych i sześciostopniowej dla istniejących: Pass $>25 \%+1$ pkt. krytyczny, Good $>40 \%+2$ pkt. krytyczne, Very good $>55 \%+4$ pkt. krytyczne, Excellent $>70 \%+11$ pkt. krytycznych Outstanding $>85 \%+11$ pkt. krytycznych Istnieje 11 punktów krytycznych i są to: oprawy oświetleniowe o wysokiej częstotliwości, instrukcja użytkowania budynku, kontrola zużycia energii przez najemców, zużycie wody, środowiskowy i społeczny kodeks postępowania wykonawców, rozruch, wydajność energetyczna, technologie bez lub niskowęglowe, monitorowanie zużycia wody, składowanie materiałów do recyclingu, ograniczenie wpływu na środowisko.

\subsection{System DGNB}

DNGB jest certyfikatem opracowanym przez Deutche Gesellschaft fur Nachhaltiges Bauen, czyli niemieckie stowarzyszenie budownictwa zrównoważonego (DGNB) we współpracy z Federalnym Ministerstwem Transportu, Budownictwa i Rozwoju Miasta. DGNB jest najmłodszym z certyfikatów - powstał w 2009 roku i do tej pory nie ma jeszcze obiektu certyfikowanego nim w Polsce. Na całym świecie do roku 2013 zostało nim certyfikowanych ok 1600 obiektów [5]. DGNB obejmuje 6 aspektów budynku: Aspekt ekologiczny (15 kategorii) 23\% punktów, Aspekt ekonomiczny (2 kategorie) 22\% punktów, Aspekt społeczno kulturowy (17 kategorii) 23\% punktów, Aspekt technologiczny (10 kategorii) 23\%, Aspekt jakości procesu (13 podkategorii) 10\%, Aspekt lokalizacji (8 podkategorii) - dodatkowy aspekt. W zależności od ilości punktów budynek lub zespół urbanistyczny może otrzymać ocenę: Bronze (50\%-64,9\% pkt.), Silver (Bronze + 65-79,9\% pkt.), Gold (Bronze + Silver + 80\% pkt. i więcej). 
Warunkiem koniecznym do otrzymania certyfikatu na każdym poziomie jest spełnienie dwóch punktów krytycznych Są to: zawartość LZO w wybranych pomieszczeniach, nieprzekraczająca $3000 \mathrm{mikro} \mathrm{g} / \mathrm{m}^{3}$, oraz zawartość formaldehydu nieprzekraczająca $120 \mathrm{mikro} \mathrm{g} / \mathrm{m}^{3}$; Konieczność posiadania przez budynek udogodnień dla osób niepełnosprawnych we wszystkich ogólnodostępnych przestrzeniach. Popularność DNGB rośnie jednak w tym momencie, jest certyfikatem dużo mniej rozpowszechnionym niż LEED czy BREEAM.

\section{Porównanie certyfikatów LEED, BREEAM, DGNB}

\subsection{Porównanie popularności}

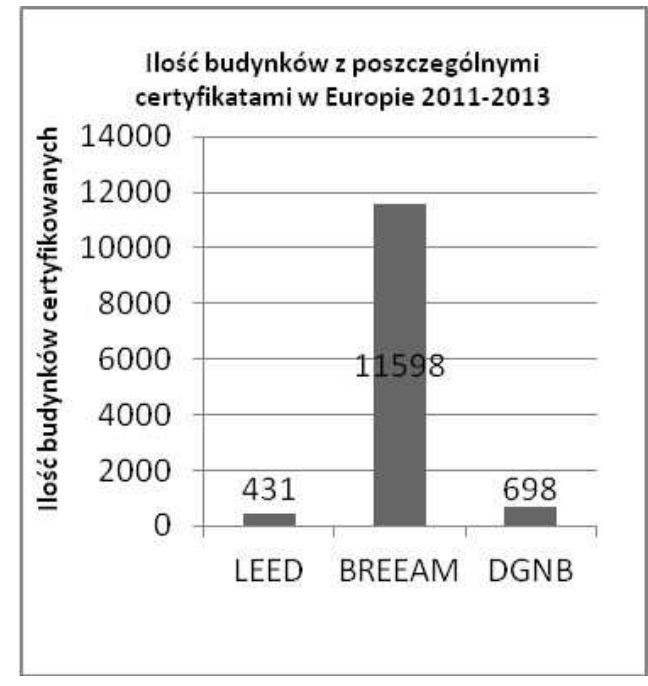

Rys. 1. Proporcje ilości przyznanych certyfikatów Europie, na podstawie [6]

Fig. 1. Amount of cert. buildings in Europe, based on [6]

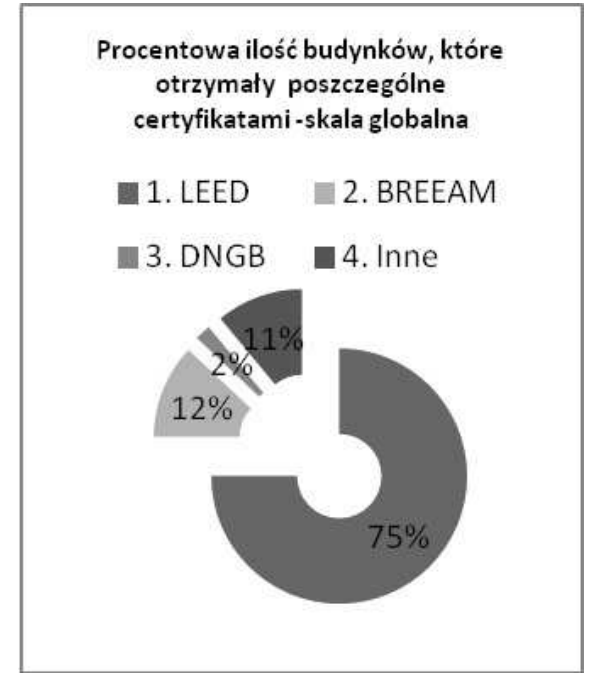

Rys. 2. Proporcje ilości przyznanych certyfikatów na świecie, na podstawie [6]

Fig. 2. Amount of cert. buildings worldwide, based on [6]

Z powyższych zestawień można wywnioskować, iż popularność danego certyfikatu jest największa na obszarze, na którym został opracowany. W związku z tym, globalnie najbardziej rozpowszechniony jest LEED, który dominuje przede wszystkim w Ameryce Pn., natomiast w Europie, a zwłaszcza w Wielkiej Brytanii najpowszechniejszy jest BREEAM. Jest to zasadne, głównie ze względu na fakt, iż certyfikaty powstawały przede wszystkim w nawiązaniu do specyfiki swojej lokalizacji. W procesie ich rozwoju, wykształcały się ich kolejne odmiany, dostosowane do Państw, w których powstawały, jednak ich centra ze sztabami specjalistów i konsultantów rozwijały się przede wszystkim w krajach macierzystych i najbliżej z nimi powiązanych (LEED Kanada najwięcej certyfikatów poza USA) [3]. 


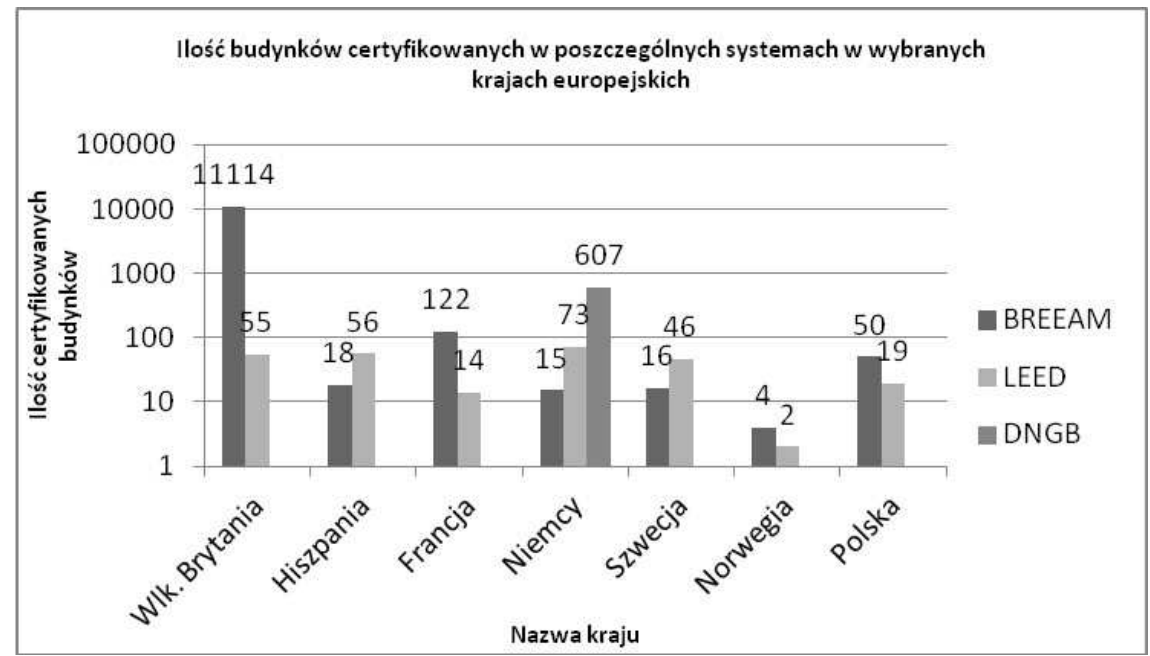

Rys. 3. Zestawienie ilości budynków certyfikowanych w systemach LEED, BREEAM I DGNB w wybranych krajach europejskich

Fig. 3. Amount of buildings certified by LEED, BREEAM or DGNB in selected European countries

W powyższym porównaniu, zdecydowano się na zestawienie krajów o zróżnicowanym nominalnym PKB w latach analogicznych do lat, w których powstawały dane budynki [7]. Na tej podstawie można zaobserwować, iż kraje z najwyższym PKB-, czyli Niemcy, Francja i Wielka Brytania, mają także największą ilość budynków certyfikowanych. Co ciekawe, obydwa te kraje wypracowały i rozwinęły własny system certyfikacji (Nieuwzględniony w artykule HQE). Kraje oscylujące w okolicach średniej wartości PKB, - czyli Szwecja, Hiszpania, czy Polska mają odpowiednio zbliżone ilości budynków certyfikowanych, w żadnym z tych krajów nie występuje certyfikat DGNB. Ciekawym przykładem jest Norwegia, która pod względem PKB plasuje się na podobnych miejscach jak Szwecja czy Polska, natomiast pod względem ilości certyfikatów jest na jednym z ostatnich miejsc w Europie, pomimo tego, że jako jeden z niewielu krajów posiada własną wersję certyfikatu BREEAM- BREEAM Norway.

\subsection{Kryteria oceny}

Jak można zaobserwować (rys. 4) BREEAM posiada najwięcej składowych na poziomie aspektów. Wartości każdej z nich oscylują wokół podobnych wartości, nieznacznie większy nacisk jest położony na aspekt energii oraz środowiska wewnętrznego i komfortu użytkowników. W aspekcie energii mieści się przede wszystkim poziom zużycia energii oraz kwestie związane z emisją $\mathrm{CO}_{2}$. W aspekcie komfortu poruszany jest problem światła dziennego, jakości powietrza, komfortu termicznego, akustycznego obecności legionelli itp. 


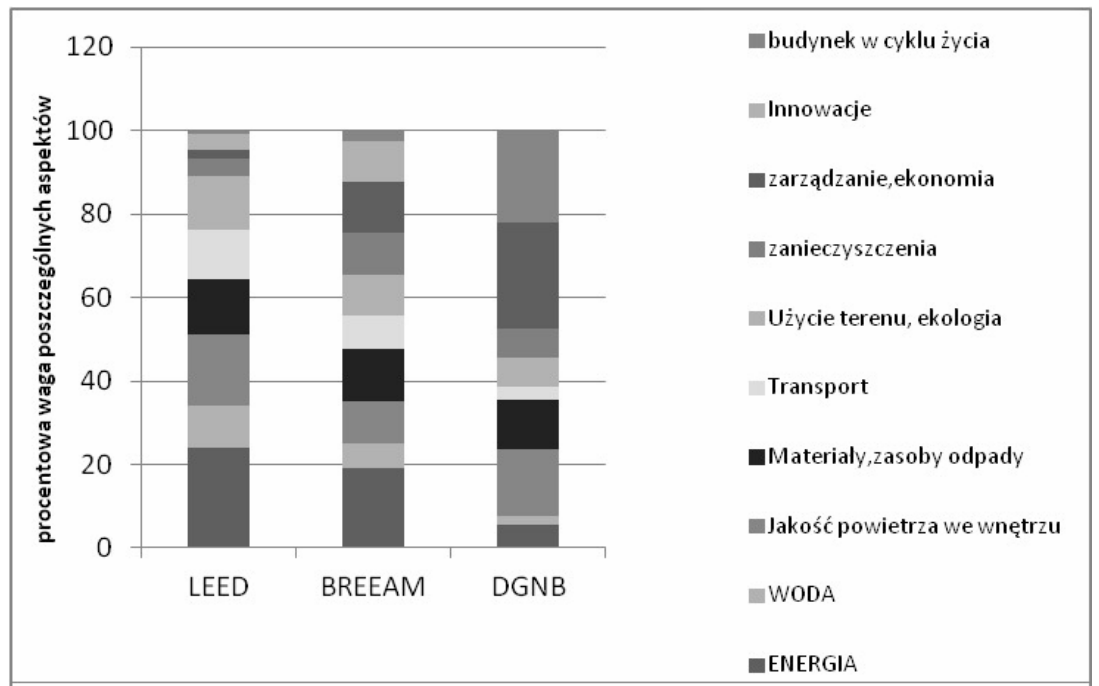

Rys. 4. Wagi poszczególnych aspektów

Fig. 4. Importance of particular aspects

Problemem może być zbyt duże rozdrobnienie, utrudniające sformułowanie jasnych zasad certyfikacji.), BREEAM bazuje na prawodawstwie brytyjskim i unijnym, pozwala jednak na uwzględnienie lokalnej specyfiki rynków nieruchomości. W kontekście zrównoważonego rozwoju, także brakuje mu filaru ekonomicznego, jednak uwzględnia zarządzanie procesem, jako osobny aspekt. LEED z kolei kładzie zdecydowanie większy nacisk na aspekt energii i atmosfery, w którym zawiera się przede wszystkim optymalizacja zużycia energii, a także użycie odnawialnych źródeł energii. Kolejnym ważnym aspektem jest zrównoważona lokalizacja, która zawiera w sobie kryteria związanie z wyborem lokalizacji, transportem, ochroną ekosystemów. LEED jest uważany za certyfikat najbardziej ukierunkowany na ekologię i tzw. Zielone budynki. Mniej można go rozpatrywać w kategoriach zrównoważonego rozwoju, ze względu na zdecydowany brak jednego z filarów tegoż rozwoju, czyli aspektu ekonomicznego. W odróżnieniu od BREEAMU przyznaje jednak punkty za aspekty regionalne bazuje jednak na wiedzy i doświadczeniu Amerykańskiego Stowarzyszenia Inżynierów Ogrzewnictwa, Chłodnictwa i Klimatyzacji.

Twórcy DNGB w związku z tym, że powstał on najpóźniej, mieli możliwość obserwacji pozostałych dwóch systemów certyfikacji i wyciągnięcia wniosków przy tworzeniu własnego. DGNB charakteryzuje się najbardziej zrównoważonym podziałem aspektów, ale jednocześnie dużą przekrojowością przez zagadnienia, które porusza. Ma właściwie cztery porównywalnie istotne aspekty, tj. ekologia, zagadnienia społeczne, technologia i ekonomia. Jako jedyny w znaczący sposób obejmuje aspekt ekonomiczny, w którym zawiera m.in. koszty budynku w jego cyklu życia. Istotny w tym systemie jest także aspekt, jakości powietrza we wnętrzu, do niego też odnosi się jeden z wymogów krytycznych. 


\subsection{Symulacja implementacji każdego z systemów w tym samym obiekcie}

Pod koniec 2010 roku duński instytut rozwoju i badań nad budownictwem przeprowadził eksperyment, w którym zespół specjalistów reprezentujących każdy z czterech systemów certyfikacji (LEED, BREEAM, DNGB, HQE), przeprowadził niezależną certyfikację tego samego obiektu $\mathrm{w}$ danym systemie. Wybrany obiekt to budynek biurowy, o powierzchni $6000 \mathrm{~m}^{2}$, którego budowa została zakończona w 2009 roku. Przyjęto kryteria dla budynków nowopowstających. Budynek nie był budowany pod kątem wymagan któregokolwiek systemu. Wyniki pokazały, że obiekt uzyskałby certyfikat w każdym systemie, z tym, że na różnych poziomach. Instytut rozwoju nad budownictwem wykazał, że każdy z certyfikatów na poziomie pewnej ogólności porusza zbliżone zagadnienia. Różnice pojawiają się $\mathrm{w}$ detalach, podejściu do określonych zagadnień. oraz kwestiach formalnych (dokumentacji). Budynki osiągnęły dość wysokie wyniki w kryteriach związanych z energią, środowiskiem wewnętrznym, odpadami i transportem, natomiast gorszą pod względem wody, materiałów, otoczenia i innowacji. Autorzy podkreślili konieczność adaptacji każdego z systemów do warunków regionalnych. Duńskie badanie pokazuje, iż na pewnym poziomie jest możliwe uzyskanie każdego z certyfikatów, bez konieczności wybitnego dostosowania się do ich wymogów na każdym poziomie realizacji obiektu. Jednakże, w przypadku chęci otrzymania certyfikatów na najwyższych poziomach, nie jest to możliwe bez odpowiednich konsultacji i dostosowań, od fazy projektowej do końcowej.

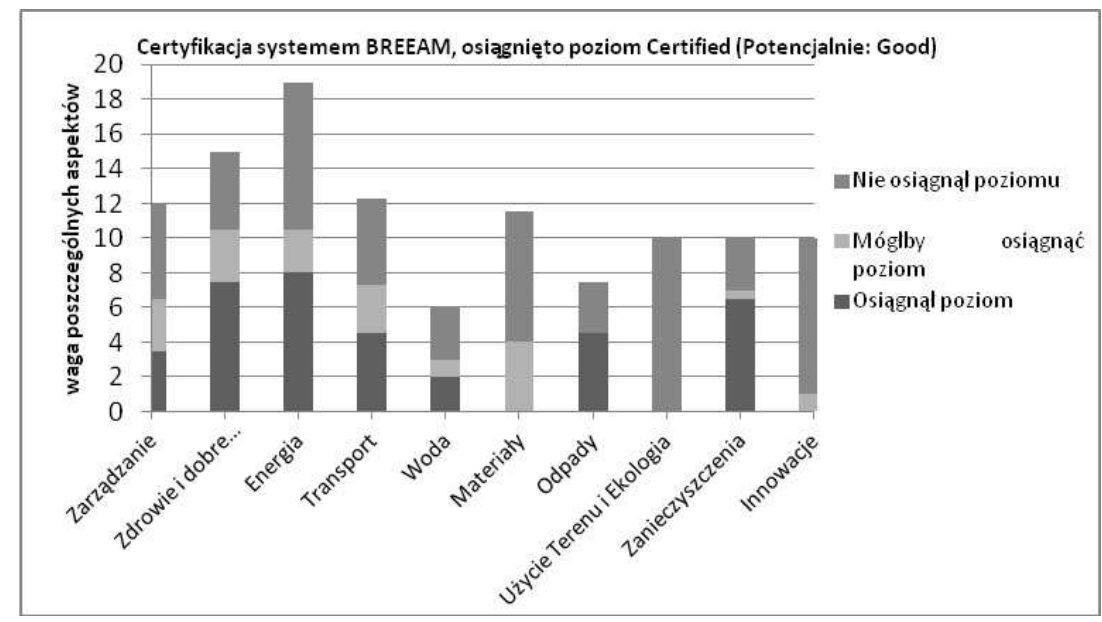

Rys. 5. Certyfikacja budynku biurowego przy pomocy systemu BREEAM, na podstawie [8]

Rys. 5. Certification of office building, using BREEAM system, based on [8] 


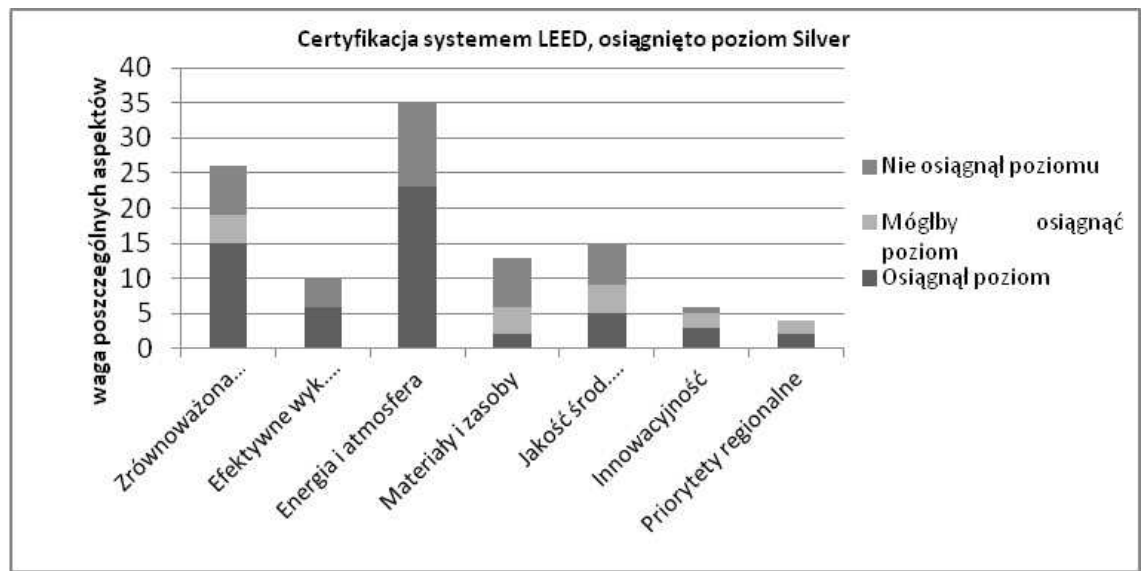

Rys. 6. Certyfikacja budynku biurowego przy pomocy systemu LEED, na podstawie [8] Rys. 6. Certification of office building, using LEED system, based on [8]

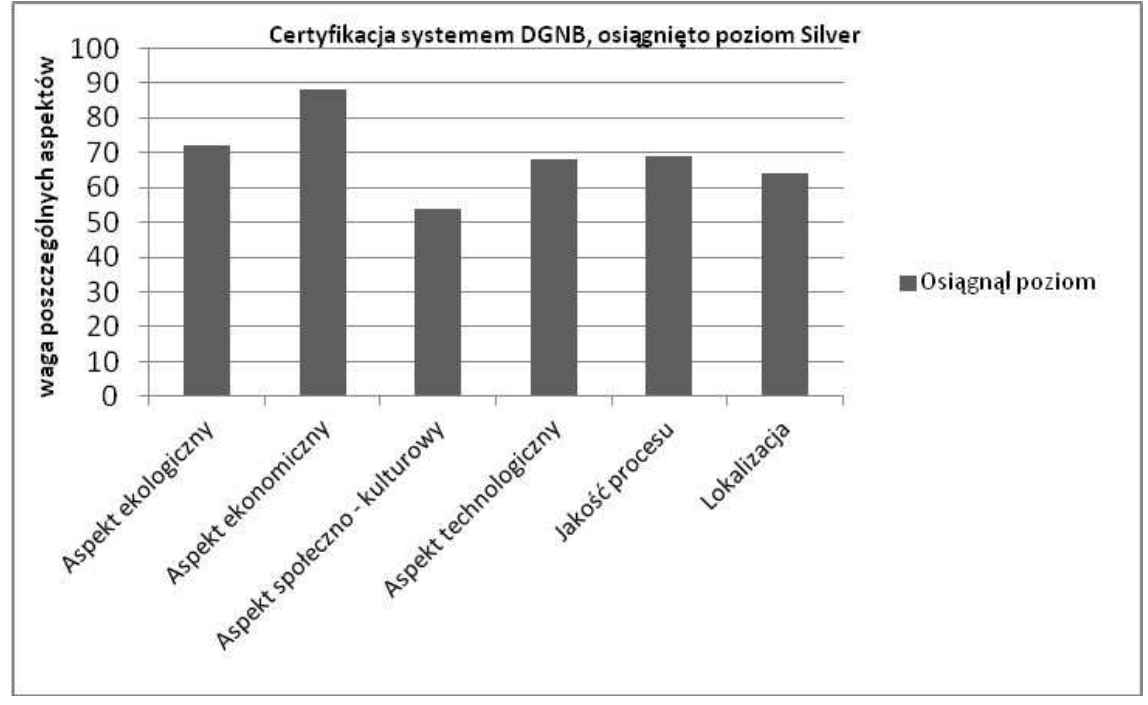

Rys. 7. Certyfikacja budynku biurowego przy pomocy systemu DGNB, na podstawie [8] Rys. 7. Certification of office building, using DGNB system, based on [8] 


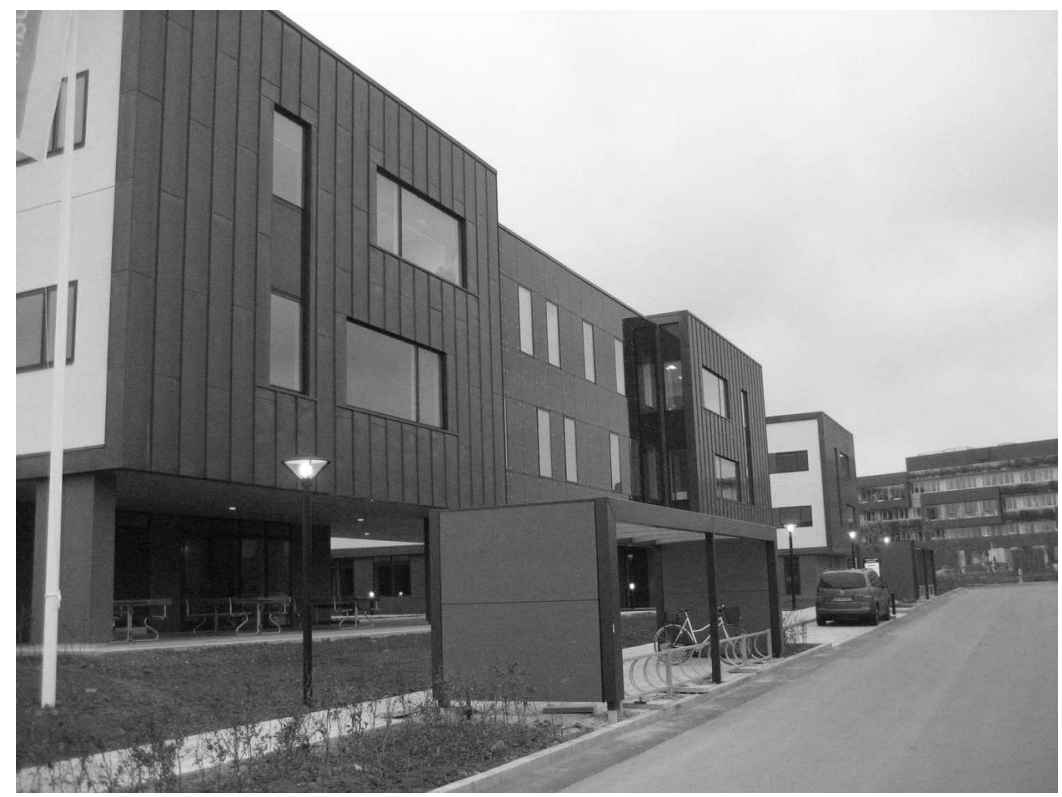

Rys. 8. Budynek biurowy, poddany trzem systemom certyfikacji, Company house w Danii [13]

Rys.8. Office building, on which certification systems were simulated, Company house in Denmark [13]

\section{Podsumowanie}

\subsection{Zasadność stosowania}

Zasadność stosowania certyfikatów można rozpatrywać w kilku aspektach. W kontekście oszczędności surowców w eksploatacji, czyli np. oszczędności energii, zakłada się, że budynki certyfikowane zużywają jej mniej. Każdy z certyfikatów przyznaje odpowiednie ilości punktów za zmniejszenie zużycia energii w stosunku do standardowego budynku. Najmniej, bo tylko $10 \%$ punktów przyznaje DGNB, co jednak może wynikać z wysokich wymagań dot. Ograniczenia zużycia energii w Niemczech, niezależnie od certyfikacji. Najwięcej punktów z kolei za oszczędności w energii przyznaje LEED, jednak zgodnie z badaniami [6] średnio 100 budynków w Stanach Zjednoczonych certyfikowanych LEEDEM zużywa ok. 18-39\% mniej energii na $\mathrm{m}^{2}$ niż standardowe budynki. Jednak z tych samych badań wynika, że $28-35 \%$ budynków zużywa więcej energii, niż standardowe. Oznacza to, że inwestorzy są w stanie uzyskać wymagane progi punktowe, pomijając aspekt energetyczny. Analogicznie w BREEAM, wymagania energetyczne są niezbędne tylko przy dwóch najwyższych stopniach certyfikatu. Są to bez wątpienia słabe punkty certyfikacji. W kontekście ekonomicznym, z analiz wynikają często sprzeczne informacje, spowodowane tym, że na wielu rynkach światowych są to wciąż rozwiąza- 
nia nowe i mało popularne. Źródła podają, iż osiągnięcie najniższych not w certyfikacji to wzrost kosztu budynku od 0 do $3 \%$, natomiast najwyższych nawet do 7\% [9]. Koszty można jednak zoptymalizować, jeżeli przystąpi się do procesu certyfikacji odpowiednio wcześniej i pod jego kątem przeprowadzi się cały proces inwestycyjny [10]. Kolejnym aspektem związanym z obiektami komercyjnymi jest fakt, iż w „,zielonych” budynkach, stawki czynszów są wyższe szacunkowo o 2-6\%, i rosną szybciej niż w standardowych obiektach. Charakteryzują się także większym stopniem powierzchni wynajętych, co także generuje zysk [9]. Wartość rynkową, którą zyskują dzięki certyfikatom zielone budynki określa się, jako „green value”, czyli zieloną wartość dodaną do standardowej wartości obiektu [11]. Jest to nie tylko wyższy koszt czynszu i jego szybszy wzrost, ale także dużo wyższe ceny sprzedaży obiektów z certyfikatami - nawet o $16 \%$ przewyższające ceny standardowych obiektów [12]. Uzasadnienie opłacalności finansowej obiektów certyfikowanych opiera się, więc na podstawowym założeniu, kalkulacji kosztów w całkowitym procesie użytkowania obiektu, a nie jedynie kosztu budowy i pierwszych lat eksploatacji. W aspekcie społecznym, także ciężko jest jednoznacznie ocenić korzyści i wady. Bez wątpienia pozytywnym zjawiskiem, jest to, że komfort użytkowników jest brany pod uwagę $\mathrm{w}$ wielu aspektach. Budynki certyfikowane poprawiają środowisko pracy i życia. Zgodnie z raportem UE pracownicy „zielonych” budynków biorą zwolnienia lekarskie o 30-50\% rzadziej niż ich koledzy w innych biurowcach.

\subsection{Wnioski}

Sektor budownictwa został zdefiniowany przez UE, jako posiadający największy potencjał w zmniejszeniu zużycia energii, ale także - jak wspomniano na początku artykułu, jako zużywający $40 \%$ energii w Unii. $Z$ tego względu. Istotnym jest, aby próbować minimalizować jego negatywny wpływ na środowisko. Certyfikaty wielokryterialne, pomimo wątpliwości, które budzą, mają jedną niewątpliwą zaletę- zwracają uwagę na zrównoważony rozwój i prowokują do dyskusji. Faktem jest, że obecnie, każdy z systemów posiada wiele minusów i niedociągnięć, a także prowadzi do zwiększenia biurokracji w cyklu inwestycji, jednak niewątpliwie wpływa także, na jakość budynku, podkreślając zużycie surowców, komfort użytkowników, czy materiały, z których jest zbudowany. Być może w przyszłości należałoby skoncentrować się na unifikacji systemów certyfikacji, tworząc zamiast kilku systemów o trudnych do porównania kryteriach, jeden wiodący, który łączyłby w sobie najlepsze cechy każdego z nich. Pozwoliłoby to na dynamiczniejszy rozwój systemów certyfikacji i możliwość łatwego porównywania budynków na rynkach nieruchomości. Ciekawym rozwiązaniem było by także stworzenie certyfikatu, który dokładnie odpowiadałby na wymogi dyrektywy EPBD wprowadzonej przez Unię Europejską i który mógłby rozwijać się wraz z rozwojem przepisów unijnych. Pozwoliłoby to bezpośrednio powiązać cele Unii dotyczące zmniejszenia zużycia energii w budynkach i dążenia inwestorów, którzy dostrzegają liczne korzyści ekonomiczne związane z certyfikacją obiektów. 


\section{Literatura}

[1] Deklaracja z Rio w sprawie środowiska i rozwoju , Konferencja NZ Środowisko i Rozwój, Rio de Janeiro, Brazylia 1992 http://www.mipe.oswiata.org.pl/rozwoj/ doc/deklaracja_z_rio.pdf. [dostęp 20.04.2014].

[2] Gutowski A;Wójcik J; Wypych R: Zielone Budynki w Polsce, Raport 2014, Colliers international ,www.propertynews.pl/media/plik/15405.html [dostęp 29.04.2014].

[3] U. S Green building council http://www.usgbc.org/projects [dostęp 29.04.2014].

[4] BREEAM http://www.breeam.org/page.jsp?id=559 [dostęp 29.04.2014].

[5] DGNB http://www.dgnb-system.de/en/projects/ [dostęp: 06.05.2014].

[6] Colliers international, http://www.colliers.com [dostęp 05.2014].

[7] http://wdi.worldbank.org/tables [dostęp 06.05.2014].

[8] Birgisdóttir H. Lesson learned from testing four different certification methods for buildings, LEED, BREEAM, DGNB, HQE, Raport 2010, Danish Building Research Institute http://www.vbr.is/files/HarpaBirgisdottir120511.pdf [dostęp 29.04.2014].

[9] Who Pays for Going Green? The Economics of Sustainable Buildings, Raport Richard Ellis, 2009, portal.cbre.eu/.../emea_economics_of_sustainable_buildings/report [dostęp 29.04.2014].

[10] Janicka K. Zielone budynki biurowe na rynku nieruchomości w Polsce, Kwartalnik nauk o przedsiębiorstwie nr 1/2014, str.57-65.

[11] A comparison of green building certifications in Europe: How does it apply to practice [W]:Lux real forum of sustainability 2013, http://www.oai.lu/files/ actualites/2013/2013_01_31_PwC_LRouach_Presenttion_LuxReal_FORUM_Sustainabi lity_January_2013.pdf [dostęp 29.04.2014].

[12] Eichholtz P. Doing Well by Doing Good? An Analysis of the Financial Performance of the Green Office Buildings in the USA, Maastricht University and California University raport 2009 http://www.ucei.berkeley.edu/PDF/seminar20090130.pdf [dostęp 29.04.2014].

[13] http://www.ncc.se/press/cision-page/c4768724147b29ce/ncc-f\%C3\%83\%C2\%B6rstmed-breeam-certifierad-kontorsbyggnad-i-danmark/ [dostęp: 05.2015].

\section{INTERNATIONAL CERTIFICATION SYSTEMS LEED, BREEAM, DGNB. PRELIMINARY COMPARATIVE ANALYSIS, FOLLOWED BY CASE STUDY}

\footnotetext{
S u m m a r y

Paper concerns the issue of international building certification systems, LEED, BREEAM, DGNB. In Poland, the same as in other European union's countries, building sector consumes the biggest amount of energy - about $40 \%$ of whole usage. Due to changes in European Union law regulations, but also because of rising ecological awareness of the society, the topic of changing the attitude to designing and realization process is being held more often than before. New buildings should be designed, constructed and used with respect to environment and natural resources. Furthermore, the highest class technical solutions and materials should be used. Based on literature studies, as well as comparative analysis, author prepare the summary of mentioned systems. Analysis of popularity, criteria types, and importance of particular criteria are presented and
} 
summarized. The case study is the office building, on which was made a simulation of each certification process. It was proved, that despite of some differences, systems have some common features - in each system building achieved the certificate, but on different level. In the final part of the paper some preliminary conclusions were formulated - concerning economic, ecological and social aspects in certification systems. The aim of the paper is to synthesis information and researches on LEED, BREEAM and DGNB.

Keywords: certification, architecture, sustainable development, energy

Przestano do redakcji: $26.01 .2015 \mathrm{r}$.

Przyjęto do druku: 22.06.2015 r.

DOI:10.7862/rb.2015.60 